\title{
Profil Klinik Infeksi Virus Dengue pada Bayi Di Surabaya
}

\author{
Dominicus Husada, Catarina Rani, Dwiyanti Puspitasari, Widodo Darmowandowo, \\ Parwati S. Basuki, Ismoedijanto
}

Departemen Ilmu Kesehatan Anak Fakultas Kedokteran Universitas Airlangga/RSU Dr. Soetomo, Surabaya

\begin{abstract}
Latar belakang. Di Jawa Timur didapatkan peningkatan kasus infeksi virus dengue dari 4224 (2000) menjadi 7180 (2004). Sekitar 5\% di antaranya terjadi pada bayi < 1 tahun. Bayi mempunyai karakter klinik yang unik dan tidak banyak publikasi penelitian mengenai hal ini di Indonesia.

Tujuan. Mengetahui profil klinik bayi dengan infeksi virus dengue (IVD) yang dirawat di RSU Dr. Soetomo Surabaya pada tahun 2010

Metode. Penelitian cross-sectional, menggunakan data dokumen medik bayi IVD yang dirawat di RSU Dr. Soetomo Surabaya 1 Januari - 31 Desember 2010. Data yang dianalisis mencakup jenis kelamin, usia, hari sakit saat diagnosis, suhu, batuk, diare, muntah, kejang, petekie, ensefalopati, hepatomegali, melena, dan penurunan nafsu makan. Penelitian menggunakan derajat kemaknaan 95\% (95\% CI) dan p<0,05.

Hasil. Dari 82 bayi IVD, 53 digunakan sebagai sampel. Usia termuda bayi DBD 4 bulan, dengan modus pada 4-5 bulan (masing-masing 6 bayi). Kebocoran plasma umumnya terjadi pada hari keempat dan kelima. Rasio laki:perempuan (PR 0,383), batuk (PR 0,191), ensefalopati (PR 4,5), hepatomegali (PR 2,818), dan melena (PR 3,5) merupakan gejala dan tanda klinis yang signifikan yang membedakan DD dengan DBD.

Kesimpulan. Rerata usia dan kelompok usia terbanyak setara dengan beberapa penelitian lain. Batuk dan jenis kelamin laki-laki lebih berhubungan dengan demam dengue, sedangkan ensefalopati, hepatomegali, dan melena berhubungan dengan demam berdarah dengue. Sari Pediatri 2012;13(6):437-44.
\end{abstract}

Kata kunci: bayi, infeksi virus dengue, profil klinik

$\mathrm{I}$ nfeksi virus dengue (IVD) masih merupakan beban besar di Indonesia. Di Jawa Timur terjadi peningkatan dari 4224 kasus di tahun 2000 menjadi 7180 pada tahun 2004 yang sebagian besar (95\%)

\footnotetext{
Alamat korespondensi:

Dr. Dominicus Husada, Sp.A, DTM\&H., MCTM (TP), Kertajaya Indah VII/(G-121), Surabaya 60116. Telp. (031) 5947807, 0818337734, Fax. (031) 5501748. E-mail: dominicushusada@yahoo.com
}

menimpa anak berusia di bawah 15 tahun, dengan angka kematian di atas 1\% (data Dinkesprop Jawa Timur). Berbagai laporan secara umum menyebutkan sekitar $5 \%$ kasus demam berdarah dengue ( = DBD, termasuk sindrom syok dengue/SSD ) terjadi pada bayi (usia kurang dari 1 tahun). ${ }^{1,2,3}$ Penelitian di Bangkok tahun 1960-an mendapatkan angka 10\%.,

Infeksi virus dengue memiliki spektrum klinik yang luas, mulai dari tanpa gejala, demam tidak khas, demam 
dengue (DD) hingga demam berdarah dengue yang mengancam jiwa. Gejala klinik dapat dibagi tiga fase yaitu fase demam (hari 1-3), fase kritis/demam turun (hari 3-6), dan fase penyembuhan (hari 6-10). Demam dengue mempunyai gejala demam, nyeri kepala dan nyeri otot/sendi, yang dapat disertai trombositopenia dan perdarahan. Sedangkan DBD ditandai dengan demam, perdarahan, pembesaran hati, trombositopenia, dan kebocoran plasma (dapat berwujud hemokonsentrasi, efusi pleura, asites, dan hipoalbumin) yang jika berat dapat menimbulkan syok. ${ }^{1,5}$

Demam berdarah dengue hampir selalu terjadi pada dua kelompok umur yaitu pasien dewasa dan anak dengan infeksi dengue sekunder yang heterolog, sedangkan bayi dengan infeksi primer yang lahir dari ibu yang imun terhadap IVD. Mekanisme yang paling bertanggung jawab diyakini adalah ADE (antibody dependent enhancement). ${ }^{6}$

Bayi yang menderita IVD menjadi subjek yang menarik karena beberapa alasan. Pertama, angka kematian bayi relatif lebih tinggi, sekalipun data berbagai penelitian sangat bervariasi. ${ }^{2}$ Angka kematian untuk semua usia dalam sebuah studi di Jakarta (1999) mencapai 19,7\%.7 Kedua, bayi dengan IVD primer mempunyai karakteristik unik dan lebih berpotensi menuju DBD/SSD dan membahayakan jiwa dibandingkan kelompok usia yang lebih tua. ${ }^{5}$ Ketiga, insiden bayi dengan IVD simtomatik jauh lebih kecil dibandingkan yang tanpa gejala sehingga memberi kesan bahwa angka kejadian yang sebenarnya sebetulnya lebih tinggi. ${ }^{3,5,6,8-10}$

Demam berdarah dengue pada bayi telah dilaporkan pertama kali pada tahun 1969 oleh Halstead dkk. ${ }^{4}$ Akan tetapi sejak saat itu penelitian tentang infeksi virus dengue pada bayi berjalan lambat. Baru pada era setelah 1995 publikasi menangani hal ini berkembang pesat baik dalam bentuk laporan kasus ${ }^{11-13}$ maupun penelitian yang lebih besar. ${ }^{12,14-18}$ Di Indonesia sendiri publikasi penelitian mengenai IVD pada bayi masih terbatas.

Tujuan penelitian ini untuk mengetahui profil klinik bayi yang menderita infeksi virus dengue yang dirawat di RSU Dr. Soetomo Surabaya sepanjang tahun 2010.

\section{Metode}

Penelitian dilakukan secara cross-sectional dengan data yang diambil dari dokumen medik pasien rawat inap di bangsal anak RSU Dr. Soetomo Surabaya selama periode 1 Januari hingga 31 Desember 2010. Kriteria inklusi mencakup bayi yang berusia kurang dari 1 tahun, dirawat di Instalasi Rawat Inap Anak, dan didiagnosis secara klinis dan laboratoris sebagai infeksi virus dengue (demam dengue dan demam berdarah dengue) menurut Pedoman WHO 1997. Hasil pemeriksaan serologis imunoglobulin M dan G memperkuat diagnosis. Data demografik dan klinis yang dianalisis adalah jenis kelamin, usia, hari sakit saat diagnosis, suhu, batuk, diare, muntah, kejang, petekie, ensefalopati/penurunan kesadaran, hepatomegali, melena, dan penurunan nafsu makan. Pemeriksaan darah lengkap dilakukan serial, sedikitnya dua kali selama masa perawatan. Hemokonsentrasi sebesar minimal 20\% dihitung ulang dengan membandingkan kadar hematokrit maksimum (saat trombosit mencapai titik terendah) dengan kadar hematokrit sebelum pasien dipulangkan. Sampel dibagi menurut kelompok demam dengue dan demam berdarah dengue, dan selanjutnya data dianalisis serta dilengkapi penghitungan rasio prevalens (PR). Penelitian ini menggunakan derajat kemaknaan 95\% (95\% CI) dan $\mathrm{p}<0,05$. Analisis statistik dilakukan dengan memakai software SPSS versi 17.

\section{Hasil}

Di antara 82 bayi yang menderita IVD yang dirawat selama tahun 2010 didapatkan 53 bayi yang memenuhi kriteria inklusi. Sisa 29 bayi lainnya tidak diikutsertakan karena dokumen medik tidak ditemukan, dokumen medik tidak lengkap, atau dirawat tidak di IRNA Anak. Rincian diagnosis ke53 bayi adalah demam dengue 35 bayi, $\mathrm{DBD} \mathrm{I}=3$, DBD II $=6$, dan DBD III = 9 bayi. Satu bayi DBD III meninggal dunia akibat perdarahan sedangkan sisanya pulang dalam keadaan sembuh.

Jumlah seluruh penderita bayi dan anak dengan infeksi virus dengue di IRNA Anak RSU Dr. Soetomo sepanjang tahun 2010 sebanyak 1140 pasien. Dengan demikian jika seluruh 82 kasus diperhitungkan, insidens IVD pada bayi untuk tahun 2010 sebesar $7,2 \%$. Insidens dengan hanya memperhitungkan 53 penderita adalah $4,7 \%$.

Distribusi usia, jenis kelamin, hari demam, suhu, dan gejala serta tanda klinis dari kedua kelompok tertera pada Tabel 1 dan 2. Demam dialami oleh seluruh pasien di kedua kelompok. Usia termuda 
Dominicus Husada dkk: Profil klinik infeksi virus dengue pada bayi

Tabel 1. Distribusi usia, jenis kelamin dan suhu badan bayi menurut derajat infeksi virus dengue

\begin{tabular}{lcccc}
\hline Variabel & $\begin{array}{c}\text { Kelompok DBD } \\
(\mathrm{n}=18)\end{array}$ & $\begin{array}{c}\text { Kelompok DD } \\
(\mathrm{n}=35)\end{array}$ & $\mathrm{p}$ & $\begin{array}{c}\text { Rasio prevalens } \\
(95 \% \mathrm{CI})\end{array}$ \\
\hline $\begin{array}{l}\text { Usia (bulan); } \\
\text { rerata }(95 \% \mathrm{CI})\end{array}$ & $7,39(6,28-8,50)$ & $8,12(7,44-8,80)$ & 0,251 & \\
$\begin{array}{l}\text { Jenis kelamin } \\
\text { (laki/perempuan) }\end{array}$ & $6 / 12$ & $24 / 11$ & $0,014^{*}$ & 0,383 \\
$\begin{array}{l}\text { Hari sakit saat diagnosis } \\
\text { (hari); rerata (95\% CI) }\end{array}$ & $4,33(3,85-4,82)$ & $4,41(3,99-4,83)$ & 0,757 & $(0,1696-0,8666)$ \\
$\begin{array}{l}\text { Suhu }\left({ }^{\circ} \mathrm{C}\right) ; \\
\text { rerata }(95 \% \mathrm{C})\end{array}$ & $37,61(37,24-37,98)$ & $37,89(37,56-38,22)$ & 0,196 & \\
${ }^{*}=$ bermakna & & & & \\
\end{tabular}

Tabel 2. Gejala dan tanda klinis pada bayi menurut derajat infeksi virus dengue

\begin{tabular}{lcccr}
\hline Variabel & $\begin{array}{c}\text { Kelompok DBD } \\
(\mathrm{n}=18) \\
\mathrm{n}(\%)\end{array}$ & $\begin{array}{c}\text { Kelompok DD }(\mathrm{n}=35) \\
\mathrm{n}(\%)\end{array}$ & $\mathrm{p}$ & $\begin{array}{c}\text { Rasio prevalens } \\
(95 \% \mathrm{CI})\end{array}$ \\
\hline Nafsu makan menurun & $5(27,8)$ & $10(28,6)$ & 0,952 & \\
Batuk & $2(11,1)$ & $19(54,3)$ & $0,002^{*}$ & $0,191(0,0487-0,7444)$ \\
Diare & $10(55,6)$ & $10(28,6)$ & 0,055 & \\
Muntah & $8(44,4)$ & $18(51,4)$ & 0,630 & \\
Kejang & $6(33,3)$ & $5(14,3)$ & 0,105 & \\
Petekie & $6(33,3)$ & $16(45,7)$ & 0,386 & $4,5(2,605-7,773)$ \\
Penurunan kesadaran & $8(44,4)$ & 0 & $<0,001^{*}$ & $2,818(1,2493-6,3574)$ \\
Hepatomegali & $12(66,7)$ & $10(28,6)$ & $0,008^{*}$ & 2,05 \\
Melena & $4(22,2)$ & 0 & $0,010^{*}$ & $3,5(2,248-5,449)$ \\
${ }^{*}=$ bermakna & \multicolumn{3}{c}{}
\end{tabular}

Tabel 3. Perbandingan hasil pemeriksaan laboratorium pada bayi dengan infeksi virus dengue

\begin{tabular}{lccc}
\hline \multicolumn{1}{c}{$\begin{array}{c}\text { Pemeriksaan } \\
\text { laboratorium }\end{array}$} & $\begin{array}{c}\text { Kelompok DBD }(\mathrm{n}=18) \\
\text { rerata }(95 \% \mathrm{CI})\end{array}$ & $\begin{array}{c}\text { Kelompok DD }(\mathrm{n}=35) \\
\text { rerata }(95 \% \mathrm{CI})\end{array}$ & $\mathrm{p}$ \\
\hline Hemoglobin $(\mathrm{g} / \mathrm{dl})$ & $11,6(10,56-12,64)$ & $11,26(10,91-11.61)$ & 0,652 \\
Leukosit $(/ \mathrm{mm} 3)$ & $8005,56(6225,55-9785,56)$ & $6648,57(5685,61-7611,54)$ & 0,195 \\
Hematokrit $(\%)$ & $34,08(30,97-37,20)$ & $33,35(32,14-34,56)$ & 0,873 \\
Trombosit $(/ \mathrm{mm} 3)$ & $43111,11(31080,42-55141,80)$ & $78942,86(64895,15-92990,57)$ & $0,002^{*}$
\end{tabular}

- Data lab diambil hanya yang terburuk selama perjalanan penyakit

- $^{*}=$ bermakna

pasien demam berdarah dengue adalah 4 bulan. Jumlah pasien DBD terbanyak adalah pada usia 4 dan 5 bulan (masing-masing 6 pasien).

Efusi pleura sebagai salah satu manifestasi kebocoran plasma dijumpai pada 17 dari 18 pasien DBD (94,4\%). Seluruh pasien dengan penurunan kesadaran atau ensefalopati menunjukkan peningkatan serum transaminase hepar dan satu di antaranya juga mengalami hiponatremia berat. Perbandingan hasil pemeriksaan laboratoris pada kedua kelompok tertera pada Tabel 3 dan Gambar 1.

Trombositopenia $\left(<100.000 / \mathrm{mm}^{3}\right)$ dijumpai pada $100 \%$ bayi DBD sementara pada DD ada 10 bayi $(28,6 \%)$ yang memiliki trombosit di atas $100.000 /$ 

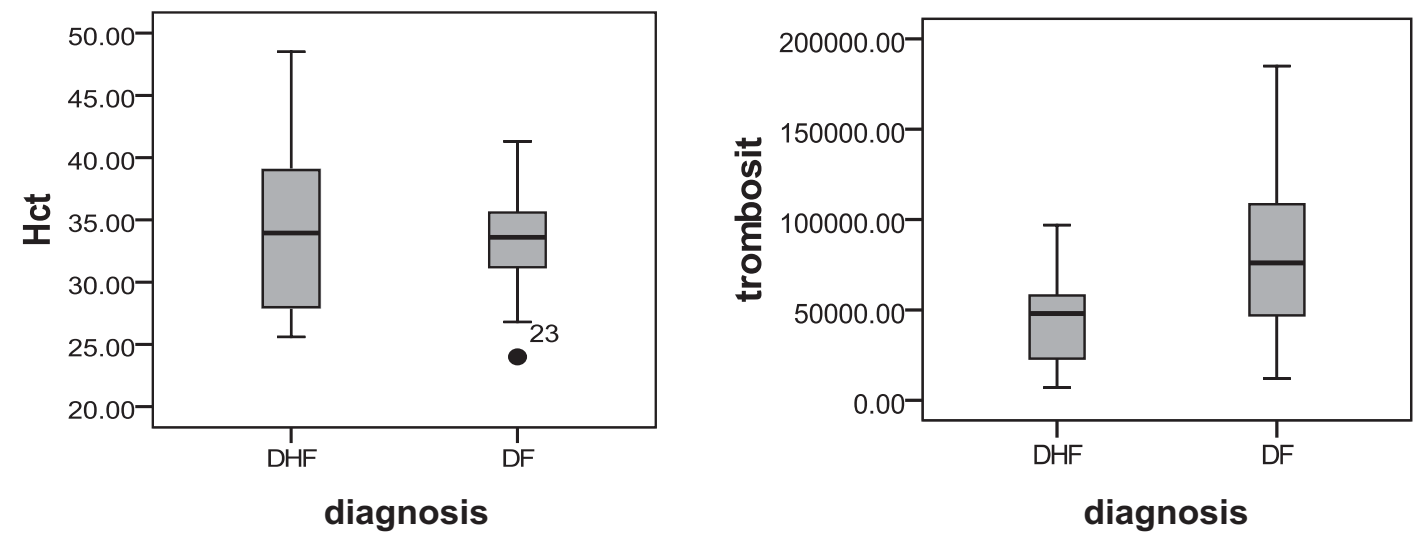

Gambar 1. Stem and leaf plot parameter hematokrit dan trombosit kedua kelompok (Perbedaan bermakna hanya pada trombosit, $\mathrm{p}=0,002$ )

$\mathrm{mm}^{3}$. Didapatkan pula korelasi bermakna antara kadar trombosit dan diagnosis DD/DBD ( $\mathrm{p}=0,001)$.

Dari 53 bayi, hanya 15 yang mempunyai data serologis. Seluruh lima bayi di kelompok DD dan 9 dari 10 di kelompok DBD yang mempunyai data serologis menunjukkan infeksi primer dengan dominasi Ig M (Ig G negatif).

\section{Pembahasan}

\section{Insidens, kematian, usia, dan jenis kelamin}

Insidens IVD pada bayi sepanjang tahun 2010 di RS Dr. Soetomo Surabaya 4,7\%-7,2\% yang setara dengan beberapa penelitian lain di berbagai tempat., ${ }^{2,3}$ Data dari penelitian Halstead $\mathrm{dkk}^{3}$ yang dikumpulkan di empat negara (Vietnam, Thailand, Myanmar, dan Indonesia) menunjukkan insiden bayi DBD 5\%. Data dari Kementerian Kesehatan Thailand 1990-1994 menemukan 3\% bayi IVD (dari seluruh kasus IVD pada anak) dan kematian 6\% lebih tinggi dibandingkan kematian pasien IVD secara keseluruhan. ${ }^{19}$ Di Chennai India pada epidemi tahun 2001, dijumpai kasus infeksi virus dengue pada bayi $20 \%$ dari seluruh kasus pediatri. Empat di antaranya adalah kasus DSS, dengan usia termuda 30 hari. $^{20}$ Terdapat penelitian lain yang menyebut insidens $1 \%-5 \%$ dari seluruh kasus IVD yang dirawat di rumah sakit. ${ }^{2,21}$ Insidens DBD bayi pada penelitian Petchaburi Thailand 2,2\% dengan median umur 8 bulan, usia termuda 3 bulan, sebagian besar berusia 6-9 bulan. ${ }^{16}$
Studi komunitas di Filipina selama dua tahun ( 2007-2009 ) menemukan manifestasi IVD pada bayi sangat beragam. Insiden IVD asimtomatik pada bayi 103 per 1000 orang-tahun dan 6 kali lipat lebih tinggi dibandingkan IVD simtomatik. Insiden spesifik menurut usia 0,5 per 1000 orang untuk kelompok 3-8 bulan dan menurun pada usia 9 bulan. ${ }^{5}$ Dari 10\%-25\% bayi yang mengalami IVD simtomatik setelah infeksi primer, separuh akan muncul dengan manifestasi klinis ringan namun separuh sisanya memerlukan perawatan di rumah sakit. ${ }^{5}$ Kasus terbanyak IVD asimtomatik pada bayi terjadi pada usia 8 bulan. Sekalipun demikian tidak banyak perbedaan besarnya insiden yang spesifik menurut umur (age specific incidence) pada kelompok usia 3-8 bulan. 4,5

Rerata usia DBD dan DD dalam penelitian kami sekitar 7-8 bulan, dengan usia termuda pasien DBD 4 bulan. Kasus SSD mencapai 17\% dengan 1 pasien meninggal. Studi di Chonburi, Thailand mengungkapkan usia termuda 3 bulan, rerata usia 7,2 bulan, dan terbanyak kelompok bayi DBD berusia 5-9 bulan. ${ }^{19}$ Beberapa penelitian di Vietnam menemukan usia terbanyak 4-10 bulan ${ }^{2,3,10}$ dengan perbandingan laki:perempuan 115:86, dan 9\% di antaranya kasus SSD. ${ }^{9,10}$ Penelitian lain juga di Vietnam mendapatkan dari 245 bayi dengan DBD, 63 di antaranya $(25,7 \%)$ mengalami SSD. Rerata usia adalah 6,8 bulan, usia termuda bayi DBD 1 bulan. Rasio laki-laki : perempuan adalah 138:107, risiko laki dan perempuan untuk mengalami SSD setara. ${ }^{18}$ Penelitian Hung ${ }^{2}$ dan Hammond $\mathrm{dkk}^{3}$ di Nicaragua menemukan frekuensi terbanyak pada usia 6-9 bulan. ${ }^{21}$ 


\section{Gejala, tanda klinis, dan laboratoris}

Selain demam, diare, dan hepatomegali merupakan gejala dan tanda klinik yang terbanyak dialami pasien bayi dengan DBD dalam penelitian kami. Perbedaan gejala klinis bermakna antara kelompok DD dan DBD dijumpai pada batuk, penurunan kesadaran, hepatomegali, dan melena (selain perbedaan rasio jenis kelamin). Hasil tersebut sedikit bergeser dibandingkan dengan data tahun 2000 yang menjumpai muntah (60\%), batuk (55\%) dan diare (40\%) sebagai gejala klinik yang paling banyak didapatkan pada bayi dengan DBD di luar kriteria WHO. ${ }^{15}$

Laporan berbagai penelitian menunjukkan hasil yang bervariasi. Studi di Vietnam oleh Hung $\mathrm{dkk}^{3}$ menemukan bahwa demam tinggi, petekie, dan hepatomegali adalah temuan klinis tersering pada bayi dengan DBD. Pada penelitian tersebut SSD dialami oleh $20,5 \%$ bayi yang mengalami DBD. Di Chennai, demam, pembesaran hati, dan ruam dijumpai pada 100, 93,1, dan 55,2\% bayi dengan IVD. ${ }^{20}$ Penelitian di Chonburi Thailand (1995-1998) menemukan demam, pilek, dan hepatomegali sebagai gejala dan tanda yang banyak dijumpai pada DBD, sedangkan ruam hanya didapatkan pada $26,7 \%$ kasus. Perdarahan terbanyak tetap perdarahan kulit/petekie (58\%), dan SSD dialami oleh 32\% dari seluruh bayi dengan IVD. ${ }^{19}$ Penelitian lain pada periode 2003-2005 di Petchaburi Thailand menjumpai 14 bayi dengan DBD, hepatomegali ditemukan pada keseluruhan kasus sementara petekie hanya dijumpai pada satu bayi. ${ }^{16} \mathrm{Di}$ Filipina, studi komunitas mendapatkan kejang demam, ruam makular, petekie, dan trombositopenia sebagai gambaran klinik yang berhubungan dengan DBD. ${ }^{5}$ Dua penelitian menekankan hubungan batuk dengan DBD dibandingkan DD ataupun dibandingkan anak yang lebih tua. ${ }^{15,22}$ Pada penelitian di Surabaya tersebut, batuk lebih dijumpai pada DD.

Salomon $\mathrm{dkk}^{23}$ menemukan peningkatan kadar transaminase serum pada semua pasien IVD dengan ensefalopati. Selain itu, 6 dari 9 pasien juga mengalami hiponatremia berat. Dari 208 bayi dengan DBD/SSD di Vietnam, 8, 6, dan 13 bayi di antaranya masing-masing mengalami syok berulang, syok berkepanjangan, dan gagal nafas akut. Empat bayi di antaranya meninggal dunia. ${ }^{8}$ Secara umum, bayi mempunyai manifestasi klinis yang berbeda dengan anak yang lebih tua, dengan frekuensi trombositopenia, kebocoran plasma, kejadian syok lebih banyak, dan lebih sedikit perdarahan., ${ }^{2,21}$
Di Vietnam, hepatomegali dijumpai 93\% dan petekie 99\% namun perdarahan lain yang nyata hanya didapati pada 5\% kasus. Tanda klinis kebocoran (asites dan efusi pleura) hanya didapatkan pada $36 \%$ bayi dengan DBD. ${ }^{9}$ Penelitian Witayathawornwong ${ }^{16}$ di Petchaburi menemukan seluruh bayi dengan DBD mengalami efusi pleura dan trombositopenia yang setara dengan temuan pada studi kami. Hung $\mathrm{dkk}^{2}$ menyatakan bahwa pada pasien dengan kebocoran plasma, tidak semua kenaikan hematokrit lebih dari 20\%. Ditemukan 8,4\% subjek penelitian yang menunjukkan kenaikan hematokrit antara 10\%-19\%. Sekalipun demikian, 8 dari 9 bayi tersebut mengalami efusi pleura kanan atau bilateral. Keadaan serupa dijumpai pada 11 dari 31 bayi penelitian Petchaburi. Di Nicaragua, hanya $12 \%$ bayi IVD mengalami efusi pleura. Studi kami juga menemukan bahwa proporsi bayi IVD yang mengalami kebocoran plasma relatif lebih besar dibandingkan anak yang lebih tua maupun kelompok dewasa. ${ }^{16,21}$

Di Chennai hampir semua bayi dengan IVD mengalami trombositopenia, dan rerata jumlah trombosit bayi lebih rendah dibandingkan anak yang lebih tua usianya. ${ }^{20}$ Pada penelitian di Surabaya ini, sekalipun trombositopenia didapatkan pada seluruh bayi dengan DBD dibandingkan dengan $79 \%$ di Nicaragua, dan hampir $100 \%$ di Chennai, hanya $33 \%$ di antaranya mengalami petekie, dan lebih sedikit lagi $(22 \%)$ yang mengalami melena. Hasil ini masih lebih besar dibandingkan gambaran di Chennai yang menjumpai hematuria dan melena pada 3,4\% kasus. ${ }^{20,21}$ Di Nicaragua, bayi yang mengalami perdarahan eksternal dan ruam dijumpai pada lebih dari $50 \%$ bayi dengan IVD. ${ }^{21}$ Di Chonburi dilaporkan 95\% kasus DBD mengalami trombositopenia. ${ }^{19}$ Ruam konvalesen ternyata dijumpai hanya pada 1 dari 41 dengan infeksi IVD primer (2\%) di Filipina, ${ }^{5}$ namun angka di RS Queen Sirikit Bangkok mencapai 24\%.22

Gejala dan tanda bayi dengan IVD serupa dengan penyakit demam akut non dengue lain. Dalam penelitian komunitas oleh Capeding $\mathrm{dkk}^{5}$ di Filipina mayoritas pasien pada kedua kelompok menampakkan gejala saluran nafas atas, yang agak berbeda dengan hasil studi berbasis rumah sakit di Nicaragua dan Vietnam. ${ }^{2,9,21,22}$ Hasil penelitian Filipina memberi pesan untuk para klinisi agar berhati-hati apabila menjumpai bayi degan gejala dan tanda infeksi saluran pernafasan. Secara umum, tanda yang jelas membedakan DBD dengan penyakit demam akut 
lain adalah ruam makular (dan jelas lebih banyak dibandingkan anak yang lebih tua dan dewasa).,21,22

\section{Infeksi primer dan patogenesis}

Pada penelitian kami, 14/15 bayi yang mempunyai data immunoglobulin $\mathrm{M}$ dan $\mathrm{G}$ menunjukkan infeksi primer. Penelitian di dua rumah sakit di Vietnam menjumpai proporsi infeksi primer hampir $100 \%$ dan $80 \%$ diantaranya menjadi DBD/SSD. ${ }^{9}$ Pada penelitian Hung dkk, 93,5\% bayi menunjukkan gambaran infeksi primer. Beberapa penelitian juga menyebutkan bahwa DBD/SSD pada bayi biasanya timbul pada infeksi dengue primer dengan hipotesis bahwa beratnya penyakit berhubungan dengan antibodi yang ditransmisikan secara vertikal dari ibunya. ${ }^{4,14,16,17}$

Dilaporkank 23 dari 24 kasus di India tahun 2001 menunjukkan respon Ig $\mathrm{M}$ yang dominan. ${ }^{20}$ Hasil yang agak berbeda dilaporkan dari Nicaragua, dijumpai $58 \%$ bayi usia 1 tahun mengalami infeksi sekunder. ${ }^{21}$ Di Chonburi Thailand, 95\% kasus merupakan infeksi primer. ${ }^{19}$ Penelitian Petchaburi ${ }^{16}$ menemukan 92,8\% kasus dengan infeksi primer. Beberapa studi di Thailand dan Vietnam menunjukkan proporsi infeksi primer 90\%-100\% sedangkan penelitian sebelumnya di Surabaya hanya mendapatkan angka 65\%. ${ }^{15,16,19} \mathrm{Di}$ Filipina, penelitian Libraty $\mathrm{dkk}^{6}$ menemukan 59 dari 60 bayi mengalami infeksi primer.

Bayi di bawah usia 1 tahun yang pada keadaan normal memperoleh antibodi $\operatorname{IgG}$ anti dengue dari ibunya rentan mengalami DBD/SSD pada infeksi primer. ${ }^{24}$ Menghilangnya antibodi yang diturunkan dari ibu tersebut terbukti berhubungan dengan usia puncak IVD pada bayi. ${ }^{9} 10$ Dengan kata lain, risiko DBD bayi muncul apabila antibodi maternal mencapai kadar subneutralizing. ${ }^{25}$ Memang pada saat baru dilahirkan antibodi ibu melindungi bayi dari infeksi virus dengue, namun selanjutnya setelah IgG dikatabolisasi sehingga kadarnya terus menerus menurun, risiko mengalami DBD/SSD meningkat. Efek ganda antibodi yang didapat secara pasif ini menerangkan distribusi DBD/ SSD pada beberapa penelitian, terutama DBD bayi terjadi pada usia 4-6 bulan. ${ }^{2,3,21,27}$ Penelitian Kliks dkk ${ }^{14}$ pada tahun 1988 merupakan penulis yang pertama mendeskripsikan hubungan antara infection-enhancing activity dari serum maternal pada monosit primer dengan usia pada saat anak mengalami infeksi virus dengue awal. Telah dibuktikan pula di Filipina bahwa usia saat munculnya bayi DBD simtomatis berkorelasi dengan kemampuan netralisasi anti DEN 3 yang dipantau saat baru lahir. ${ }^{6}$ Derajat penyakit IVD primer pada bayi berhubungan pula dengan respon imun yang hebat yang mungkin merupakan kompensasi dari jumlah virus di dalam darah yang tinggi. ${ }^{10}$

Antibodi yang diturunkan dari ibu akan menghilang pada 3, 4, 6, dan 9 bulan bertut-turut 3\%, $19 \%, 72 \%$, dan $99 \%$. Setelah mencapai usia satu tahun, seluruh antibodi terhadap virus dengue yang didapat dari ibunya telah musnah. Antibodi itu umumnya adalah IgG subklas 1 dan mempertahankan spesifisitasnya terhadap baik protein struktural maupun non struktural. IgG subklas 1 mungkin juga berperan besar dalam aktivasi komplemen dan terjadinya kebocoran plasma. ${ }^{28}$ Penelitian lain di RS Queen Sirikit Bangkok tahun 2008 pada hampir 450 bayi menemukan bahwa pada usia 9, 12, dan 18 bulan berturut-turut, masing-masing 23\%, 9\%, dan $17 \%$ bayi mempunyai antibodi netralisasi terhadap 1 atau lebih serotipe dengue. Di daerah yang sangat endemis, hampir semua orang dewasa termasuk ibu hamil kebal terhadap semua serotipe dengue. ${ }^{29}$

Proses patogenesis yang dijumpai pada bayi dengan infeksi virus dengue tidak sepenuhnya dapat dijelaskan dengan model secondary heterologue infection..$^{2,11}$ Epidemiologi IVD sesuai kelompok umur (termasuk patogenesis DBD pada bayi) lebih dijelaskan dengan konsep ADE (antibody dependent enhancement). ${ }^{3}$ Banyak bukti tentang enhancing dan cross-reactive neutralizing antibody menentukan epidemi dengue dan severitas penyakit . ${ }^{30}$ Derajat penyakit dalam presentasi klinis IVD pada bayi sangat berhubungan dengan respon imun pejamu. Aktivasi imun selular banyak berhubungan dengan derajat besar presentasi klinis dengue tersebut baik pada infeksi primer bayi maupun pada infeksi sekunder pada anak yang lebih tua. ${ }^{10}$ Sekalipun demikian didapati pula pengaruh faktor lain seperti fisiologi vaskular sesuai usia, maturitas imunologis, dan pada infeksi sekunder terdapat respon sel T dan sel B memori yang telah ada lebih terdahulu. ${ }^{10}$ Apoptosis nampaknya juga berperan dalam modulasi respon imun alami dan adaptif terhadap IVD. ${ }^{30}$

Gambaran sitokin pada DD berbeda dengan DBD/SSD. Konsentrasi sitokin dan kemokin dalam darah paling tinggi dijumpai pada SSD. Penemuan tersebut konsisten dengan adanya hubungan antara besarnya inflamasi sistem imun dengan kebocoran plasma. ${ }^{10}$ Peningkatan bermakna kadar IFN-gamma dan IL-10 yang dijumpai pada anak dengan infeksi 
dengue sekunder setara dengan bayi yang mengalami infeksi primer. Pada bayi tersebut juga dijumpai kenaikan TNF-alfa dan IL-6 yang berbeda dengan anak. Peningkatan sitokin tersebut berkorelasi dengan gambaran klinis dan laboratoris., ${ }^{210,24}$

\section{Kesimpulan}

Insiden IVD pada bayi di RS Soetomo Surabaya setara dengan hasil penelitian di berbagai tempat, seperti rerata usia dan kelompok usia terbanyak. Dari gejala dan tanda klinis, batuk (dan jenis kelamin laki-laki) lebih berhubungan dengan demam dengue, sedangkan ensefalopati, hepatomegali, dan melena berhubungan dengan demam berdarah dengue pada bayi. Gambaran ini agak berbeda dengan hasil penelitian di Surabaya terdahulu (2000) serta hasil beberapa penelitian lain yang bervariasi. Hampir seluruh kasus yang memiliki data serologis infeksi primer.

\section{Daftar pustaka}

1. World Health Organization. Dengue guidelines for diagnosis, treatment, prevention, and control. Geneva: WHO; 2009.

2. Hung NT, Lei HY, Lan NT. Dengue hemorrhagic fever in infants: a study of clinical and cytokine profiles. J Infect Dis 2004; 189: 221-32.

3. Halstead SB, Lan NT, Myint TT. Dengue hemorrhagic fever in infants: research opportunities ignored. Emerg Infect Dis 2002; 8: 1474-9.

4. Halstead S, Scanlon J, Umpaivit P, Udomsakdi S. Dengue and chikungunya virus infection in man in Thailand 1962-1964; IV. Epidemiologic studies in the Bangkok metropolitan area. Am J Trop Med Hyg 1969; 18: 997-1021.

5. Capeding R, Brion J, Caponpon M. The incidence, characteristics, and presentation of dengue virus infections during infancy. Am J Trop Med Hyg 2010; 82: 330-6.

6. Libraty DH, Acosta LP, Tallo V. A prospective nested case-control study of dengue in infants: rethinking and refining the antibody-dependent enhancement dengue hemorrhagic fever model. PLoS Med 2009; 6: e1000171.

7. Hadinegoro SR, Purwanto SH, Chatab F. Dengue shock syndrome: clinical manifestations, management, and outcome - a hospital based study in Jakarta, Indonesia. Dengue Bull 1999; 23: 105-6.

8. Hung NT,Lan NT, Lei HY. Volume replacement infants with dengue hemorrhagic fever / dengue shock syndrome. Am J Trop Med Hyg 2006; 74: 684-91.

9. Chau TNB, Anders KL, Hung NT. Clinical and virological features of dengue in Vietnamese infants. PLoS Negl Trop Dis 2010; 4: e657.

10. Chau TNB, Quyen NTH, Tuan NM. Dengue in Vietnamese infants - results of infection-enhancement assays correlate with age-related disease epidemiology, and cellular immune responses correlate with disease severity. J Infect Dis 2008; 198: 516-24.

11. Garcia-Campos JA, Guzman-de la Garza FJ, AlejandroQuiroga VM, Gonzalez-Ruiz MdC, Moreno-Sanchez H, Camara-Lemarroy CR. Dengue hemorrhagic fever in an infant after primoinfection. Bol Med Hosp Infant Mex 2010; 67: 355-8.

12. Soundravally R, Narayanan P, Vishnu Bhat B, Soundraragavan J, Setia S. Fulminant hepatic failure in an infant with severe dengue infection. Indian J Pediatr 2010; 77: 435-7.

13. Choudry SP, Gupta RK, Kishan J. Dengue shock syndrome in newborn - a case series. Indian Pediatrics 2004; 41: 397-9.

14. Kliks SC, Nimmanitya S, Nisalak A, Burke DS. Evidence that maternal dengue antibodies are important in the development of dengue hemorrhagic fever in infants. Am J Trop Med Hyg 1988; 38: 411-9.

15. Hidayah N, Darmowandowo W, Ismoedijanto, Soegijanto S. Dengue hemorrhagic fever in infant ( clinical aspects, immunological responses related to clinical degrees) [abstrak]. Dalam: Program and Abstracts of the $1^{\text {st }}$ International Conference on Dengue/Dengue Hemorrhagic Fever (Chiang Mai, Thailand). Geneva: World Health Organization; 2000: 11.

16. Witayathawornwong P. Dengue hemorrhagic fever among infants in Petchabun Province, Thailand: 20032005. Dengue Bull 2006; 30: 35-41.

17. Pancharoen C, Thisyakorn U. Dengue virus infection during infancy. Trans R Soc Trop Med Hyg 2001; 95: 307-8.

18. Hung NT, Lan NT, Lei HY. Association between sex, nutritional status, severity of dengue hemorrhagic fever, and immune status in infants with dengue hemorrhagic fever. Am J Trop Med Hyg 2005; 72: 370-4.

19. Hongsiriwon $S$, Dengue hemorrhagic fever in infants. Southeast Asian J Trop Med Publ Health 2002; 33: 49-55. 
20. Kabilan LL, Balasubramaniam S, Keshava SM. Dengue disease spectrum among infants in the 2001 dengue epidemic in Chennai, Tamil Nadu, India. J Clin Microbiol 2003; 41: 3919-21.

21. Hammond SN, Balmaseda A, Perez L. Differences in dengue severity in infants, children, and adults in a 3-year hospital based study in Nicaragua. Am J Trop Med Hyg 2005; 73: 1063-70.

22. Kalayanarooj S, Nimmannitya S. Clinical presentations of dengue hemorrhagic fever in infants compared to children. J Med Assoc Thai 2003; 86: 673-80.

23. Salomon T, Mihn Dung N, Vaughn D. Neurological manifestation of dengue infection. Lancet 2000; 355: 1053-9.

24. Lei HY, Huang KJ, Lin YS. Immunopathogenesis of dengue hemorrhagic fever. Am J Infect Dis 2008; 4: $1-9$.

25. Rothman AL, Ennis FA. Immunopathogenesis of dengue hemorrhagic fever. Virology 1999; 257: 1-6.

26. Chau TN, Hieu NT, Anders KL. Dengue virus infections and maternal antibody decay in a prospective birth cohort study of Vietnamese infants. J Infect Dis 2009; 200: 1893-900.

27. Figueiredo LT, Carlucci RH, Duarte G. Prospective study with infants whose mother had dengue during pregnancy. Rev Inst Med Trop Sao Paulo 1994; 36: 417-21.

28. Veeradej VW, Endy TP, Samakoses R. Transplacentally transferred maternal infant antibodies to dengue virus. Am J Trop Med Hyg 2003; 69: 123-8.

29. Pengsaa K, Limkitikul K, Luxemburger C. Age specific prevalence of dengue antibodies in Bangkok infants and children. Ped Infect Dis J 2008; 27: 461-3.

30. Basu A, Chaturvedi UC. Vascular endothelium: the battlefield of dengue viruses. FEMS Immunol Med Microbiol 2008; 53: 287-99. 